\title{
From (public?) waste to (private?) value. The regulation of private cord blood banking in Spain
}

\section{Pablo Santoro}

\begin{abstract}
The transformation of umbilical cord blood from a waste by-product to a valuable source of stem cells employed in haematological therapies has given rise to a globalised commercial sector in cord blood banking, a sector based essentially on promises of future therapies. Regulatory frameworks for these private services vary worldwide. This paper looks at the recent regulation of cord blood banking in Spain, taking this example as representative of some of the dilemmas currently faced by national regulatory agencies over biotechnological innovations. The Spanish case shows how, paradoxically, an attempt at producing a nationally comprehensive and rigorous regulatory order has led to the development of unregulated trans-national markets. This disjuncture problematises the traditional identification in transplantation practices between the nation-state, the social body and the solidarity of a national population. The paper ends by suggesting an interpretation of the cord blood case as part of recent mutations in biopolitics.
\end{abstract}

Keywords: cord blood banking, regulation, biopolitics

As it is repeatedly acknowledged, both in scholarly accounts and in the wider public agora (Nowotny et al., 2001), the field of biomedical technology is nowadays a privileged site where some of the most urgent philosophical, ethical and political issues of our times are being posed, debated and negotiated. Here, some of the innovations related to stem cell science, genetic testing, xenotransplantation, or regenerative medicine seem to be challenging the former political economy of exchange of bodily parts. Clinical, legal and, crucially, entrepreneurial innovations are giving rise to novel forms of tissue economies (Waldby and Mitchell, 2006), deployed around new hybrid entities such as the engineered tissue, the xenograft or the stem cell - what Klaus Hoeyer terms "human boundary objects", referring to the "multitude of new objects which are derived from bodies, designed to go back into them, or simply intended to live a life in a laboratory detached from the person from whom the material originated [...] 
making 'life' circulate between people" (Hoeyer, 2007: 327).

Especially interesting are the scientific and technical developments in the field of organ and tissue transplantation, an area traditionally linked to a sociopolitical discourse around values of solidarity, altruism and social cohesion (Lock, 2001). Michel Foucault famously described how the birth of modern biopolitics meant that individual bodies started to be part of a bigger project: the health - both medical and political - of national populations (Foucault, 1998). The deployment of modern systems of blood and organ procurement during the second half of the $20^{\text {th }}$ century can be seen as part of this process, through an identification between the flow of tissues, the nation-state and the health of the collective. Inside this new regime, blood, organs and tissues were reconfigured as a sort of national property, as collective 'soma' to be shared among the population, reflecting and, at the same time, promoting social solidarity and political cohesion. Richard Titmuss's famous study of blood collection systems, The Gift Relationship, first published in 1970, clearly exemplified this link between forms of allocation of human body parts and political solidarity (Titmuss, 1997). Through public systems of collection and distribution, the state was here the central actor; the nation state, its underlying ideological foundation. ${ }^{1}$

In an area as symbolically crucial as this to the interface of the political and the biomedical orders, public authorities are facing novel problems when trying to regulate new developments in the field. The hybrid character of human boundary objects defies traditional categories, as they are situated in an emerging space (between science and nature, between animal and human, between bodies and medicines, between present applications and expectations of future breakthroughs) that seems increasingly complex to integrate into existing regulatory frameworks. At the same time, and due to dynamics such as the increase of transnational exchanges, the rise of neo-liberal politics or the demise of the nation-state, the role and capacity of state actors in the governance of science and technology is at a point of redefinition. Andrew Barry indicates how the traditional space of government, which presumed a direct relation between a national population and a national territory, is being transformed into a much more fluid and de-territorialised set of spaces, defined by the trans-national circulation of technical knowledges, practices and devices. New technologies - among them, biomedical innovations - operate in zones with uncertain ends, and certainly ones that do not coincide with administrative or national boundaries. Barry proposes the concept of "technological zones" to characterise these novel spaces configured by the circulation of emerging technologies and to approach the problems related to their governance. The disjuncture between the scope of national regulations and the complexity of socio-technical arrangements raises a set of questions: "To what extent, if at all, can one talk about national technological territories having some kind of correspondence to the territories of nation-states? [...] In what ways are the borders of states and of transnational zones of governance formed and imagined technologically as well as territorially?" (Barry, 2001: 38). Undoubtedly, these issues have repercussions for the larger political constitution of contemporary societies.

This paper addresses some of the difficulties faced by current processes of 
regulation of biomedical technologies in the midst of these changes, and looks at this through the prism of a case study: private cord blood banking. Since the first successful transplant of cord blood was achieved in 1988, umbilical cord blood (UCB) has been increasingly used as a source of haematopoietic stem cells and as an alternative to bone marrow transplant in the treatment of a number of malignant blood disorders. UCB is collected at birth and banked for potential use in the future, both in public services and in private (for-profit) banks. The latter service, based on a currently non-existent clinical application, that of autologous transplant, has attracted special attention from scholars in social sciences (Waldby, 2006; Brown and Kraft, 2006; Dickenson, 2007). It has also prompted an array of legal and ethical commentaries from bodies such as the American Academy of Paediatrics, the Royal College of Obstetricians and Gynaecologists in the UK or the Comité Consultatif National d'Ethique in France, as well as comment and discussion in the main medical journals (e.g. Annas, 1999; Steinbrook, 2004; Fisk et al, 2005; Edozien, 2006).

Regulation of private UCB banks differs from one country to another, even inside the EU: commercial services are free to operate in the UK and Germany while in Italy or France they are prohibited. In this article I will look at the recent regulation of private UCB banks in Spain, taking it as somehow representative of the dilemmas faced by national regulatory actions in a situation of increasing globalisation. The regulation has been implemented in Spain through a new Act that transposes the 2004 EU Tissue and Cells Directive, a directive designed to establish a common European framework for tissues and cells. Nonetheless, and far from the automatism that the term suggests, this implementation has been rather problematic - happening in the country with the highest rates of altruistic organ donation and in the midst of a public debate following news of the Princes of Spain banking privately the cord of their first daughter. In what follows, I will present the form, problems and consequences of the solution finally adopted by the Spanish authorities to regulate private UCB banking and to accommodate it to the peculiar 'Spanish model' of organ donation (Matesanz and Dominguez-Gil, 2007), aiming to explore some of the challenges faced by national authorities when trying to control the novel and expanding tissue economies.

I will start by briefly discussing the notion of regulation as ordering, which will guide the approach to regulation adopted here, and then proceed to present the current uses of cord blood and the opposition between public and private systems of collection and banking. The presentation of the Spanish case is the central part of the paper, starting with the discourse of the National Transplant Organisation (ONT), the organisation in charge of the management of public cord blood banking and advisor for public authorities in everything related to organs, tissues and cells transplantation, and continuing with the development and consequences of the recent regulatory framework for cord blood. Attending to the unintended consequences of the regulation, particularly in its performative effects over the public-private divide and over the exportation of tissues, the paper will present an example of a paradoxical dynamics noted by Andrew Barry with respect to the governance of technological zones, namely that "efforts to forge a completely uniform [territorial] zone are likely to reveal and create 
objects and experiences that do not fit the standard (Barry, 2001: 41). What the Spanish case shows is how, paradoxically, an attempt at producing a nationally comprehensive and rigorous regulatory order has led to the development of unregulated trans-national markets. In the particular field of transplantation, this disjuncture problematises the traditional identification between the nation-state, the social body and the solidarity of a national population, identification that has been in the basis of public systems of organ and tissue donation. The paper will end, then, by indicating a more global interpretation of the cord blood case as part of contemporary mutations in biopolitics (Foucault, 1998, 2004; Rose, 2007).

\section{Regulation as ordering}

When exploring here dynamics of regulation, my perspective differs from legal or political perspectives. Drawing on Science and Technology Studies (STS) and on the idea of regulation as ordering (Brown et al., 2006), my approach tries to capture how the emergence of novel biomedicalobjectsde-stabilisecategories, challenge accepted boundaries, while, at the same time, enabling the possibility of new socio-technical relations. Acts of regulation are to be situated in the midst of these two movements, and it is in this sense that, from an STS perspective, regulation should be viewed as a form of socio-technical ordering and, also, as an instrument of collective sense-making. Sheila Jasanoff reminds us how, in the field of biotechnology, "[regulatory] frameworks constitute in effect an apparatus of collective sense-making through which national governments and publicsinterpret what biotechnologyboth promises and threatens. More specifically, national regulatory approaches help to position the ontological novelties created by biotechnology either on the side of the familiar and manageable or on the side of the unknown and perhaps insupportably risky" (Jasanoff, 2005b: 141). Furthermore, a high number of biomedical innovations and among them, crucially, what we have called human boundary objects, are characterised by forms of hybridisation that make difficult its ascription to traditional ontological frameworks. Their hybrid and fluid ontologies are mapped, oriented and ordered partly through acts of regulation. The umbilical cord is, in fact, a hybrid object, a connective and liminal tissue whose hybridity has to be contained or mimicked by regulation. ${ }^{2}$

There are two different aspects that I would like to emphasise by talking of regulation as ordering. The first one has to do with the political order: in processes of regulation, political boundaries are redrawn and new dispositions and distributions of power appear; we can think, forinstance, of theincreasing weight of trans-national regulations, or about how the influence of private actors, like pharmaceutical or biotech companies, over regulations and standards challenge the traditional role reserved to governmental actors in processes of technological governance. The second aspect is more broadly sociological: the construction of a regulatory order produces new social groups and new socio-technical networks, or modifies already formed alliances. For instance, by stating where the line between private and public sectors should be drawn, markets are produced, allowed or reinforced or, on the contrary, its creation and development are prevented. This also implies, as we shall see with the Spanish regulation of cord blood banking, that certain forms of social relations are in 
parallel produced, permitted or hindered. The objects that regulation deals with are also transformed and reconfigured in the course of regulatory decisions. For example, the way in which the current regulatory ambiguity about tissueengineered products (are they medical devices or are they pharmaceuticals?) is finally resolved will have practical consequences not only for the decision over which agency or institution will regulate them, but also for the kind of quality and safety procedures that they will be subjected to - and consequently, for how will they be finally designed and engineered (Faulkner et al., 2008).

What I propose here, then, is a way of thinking about regulation in which the technical, the political and the social orders are simultaneously co-constructed. Talking about the regulation of xenotransplantation and tissue engineering, Nik Brown and his collaborators put it similarly when explaining how "scientific and regulatory actors configure one another materially, culturally and institutionally. In other words, regulatory bodies form particular representations of corporeal bodies and in turn subject corporeality to the innovativeness of regulation" (Brown et al, 2006: 195). Anyway, this does not mean, as we shall see in the Spanish case, that the construction of a regulatory order is always a successful or harmonious process. By talking of "ordering", in the continuous tense, I want to indicate a processual development, which is continuously being re-produced and which includes its own paradoxes, pitfalls and unintended consequences.

Just to finish these preliminary remarks, I would like to present a scheme proposed by Andrew Webster, who indicates three aspects, three legs, in a regulatory system (Webster, 2008). First, we have the "regulatory institutions", the institutional bodies in charge of developing and applying the regulation. Then, there are the "regulatory instruments" developed or applied by these institutions, like, for example, laws that have to be enforced, licences that are provided to certain establishments or activities, and so on. Finally, we find the "normative culture", the legal and political values that orientate the regulatory processes. This last aspect can be identified, broadly, with the concept of national "political culture" (Jasanoff, 2005a: 21-23). This scheme resumes fairly well the form, the structure, of a regulatory order. But nonetheless, I think that we should add to the analysis other, more dynamic, aspects. We have to attend to things such as the interrelation between national and supra-national regulations, the peculiar history of regulatory processes (that is, of their creation, deployment and implementation, taking into account aspects such as: where does the regulatory demand come from, who are its promoters, which debates has it caused, which resistances has it faced, etc.), or the strictness or looseness in its application. Moreover, adhering strongly to a conceptual scheme such as the one proposed by Webster may lead us to presume a gap between technologies and regulation, rather than seeing technologies and regulatory frameworks as co-produced. The following study of the regulation of cord blood banking in Spain will, therefore, try to show the importance of the dynamic aspects in a regulatory order and of the co-ordering of technologies and regulatory frameworks, as well as attending to the difficulties and paradoxes of current processes of regulation. 


\section{Cord Blood Banking}

In 1988, the French haematologist Elaine Gluckman performed the first UCB transplant in New York, to treat a boy with Fanconi's anaemia (Gluckman et al., 1989). The only difference between this event and a usual bone marrow transplant was that, instead of using bone marrow cells, haematopoietic stem cells extracted from a sibling's umbilical cord and cryopreserved at birth were used. Since then, more than 7,000 UCB transplants have been performed worldwide. Proponents of the use of UCB for allogeneic (self-toother) transplantation argue that it has several advantages compared to bone marrow, including higher likelihood of immunological hystocompatibility, better rates of engraftment and reduced rates of rejection, as well as advantages to the donors: while the donation of bone marrow cells is difficult, long and sometimes painful (with the donor being subjected to anaesthesia), the process of collection of UCB is easy and unharmful, with no damage either for the mother or the child. ${ }^{3}$ There is still another advantage: since bone marrow collection is so demanding, normally the national and international registries gather potential donors - but not actual samples. When a donation is needed, the process takes its time: contacting the donor, performing the collection, transportation, etc. On the other hand, the banking of UCB samples permits easier access, so time can be reduced. ${ }^{4}$

Of course, this last advantage depended on the constitution of a sociotechnical system that made cord blood widely available. The 1990s saw the foundation, in many developed nations, of public banks aimed at the collection of cord blood, in line with the gift economy
(Titmuss, 1997) that has governed most national systems of blood and organ collection in the second half of the $20^{\text {th }}$ century: that is, based on anonymised donation mobilised through ideas of altruism and national solidarity. The goal of the public systems was, primarily, quantitative: without a number of samples enough to cover a significant fraction of the population's immunological spectrum, UCB transplant could not become a routine procedure. As Waldby and Mitchell note, "public banks create clinical value for cord blood through the redistributive processes of the public tissue gift economy [...] they focus on the need to accumulate tissues" (Waldby and Mitchell, 2006: 120). But public systems are not posed as an open-ended task, meaning that there is no need to collect every cord: given that a sufficient number is stored, it would simply be pointless and too expensive - to bank all cords. At the same time, there is a qualitative goal: to collect particularly samples of minority ethnic groups and rare immunological types. Currently, there are more than 250,000 units stored in public banks worldwide, and there are several transnational registries - built over previous bone marrow registries - which allow for the finding of compatible samples in other countries.

In 1992, the first UCB private bank opened its doors in the USA: the Cord Blood Registry, established as a pilot programme in part sponsored by the American Cancer Society (Gunning, 2004). Since then, a commercial sector has also developed around UCB. While public banks focus in present applications, the services offered by private companies have relied on a much more unstable terrain: that of the potential future developments. Furthermore, commercial services have enacted an entirely different 
strategy than public banks, by focusing not on an allogeneic rationale, but on the possible development of a process for autologous transplantation. That is, rather than being based on the current form of donor to host relationships (what in political terms would be qualified as redistributive), private banks offer the promise of cord blood being reimplanted in the same individual that it comes from to potentially cure a whole array of diseases, from multiple sclerosis to Parkinson's disease. In this sense, commercial banking of UCB partakes in the self-renewal dream that traverses the whole field of regenerative medicine: the substitution of a defective body that needs transplantations and transfusions from other bodies for an isolated subject that heals herself through autografts and self-regeneration (Kent et al., 2006; Cooper, 2004).

Private banks offer the collection, processing and private storage of UCB just for the donor or the donor's relatives, advertising their services as a "once-ina-lifetime opportunity" (http://cryo-cell. com) and defining the stored sample as a "biological resource that is like a 'selfrepair kit' for your child” (http://www. stemcytefamily.com/cord blood). The language of insurance and precautionary investment permeates the marketing of commercial services. Even if the potential applications of autologous transplantation remain mainly unproven, preserving UCB is offered as the gate to a potential, though unequal, double future: that of the child or a family member developing a disease and that of the biomedical evolution, in which a whole new generation of stem cell therapies will be developed. In any case, both temporal constructions are intertwined with a projection of health, illness and medicine towards an uncertain future only accessible today through a powerful form of imagination - through a language of affectivity, hopes and expectations, which constructs "futures with emotional resonance" (Brown and Kraft, 2006: 319).

What is the European position regarding private UCB banks? In response to a petition of the European Commission, the European Group on Ethics in Science and New Technologies (EGE) conveyed in 2004 an opinion about ethical aspects of cord blood banking. In that document, this advisory body discouraged banking for autologous use, on the grounds that private banks "sell a service which has presently no real use regarding therapeutic options". But even though "the activities of such banks raise serious ethical criticisms" and their "legitimacy should be questioned", the EGE concluded that "a strict ban would represent an undue restriction on the freedom of enterprise and the freedom of choice of individuals/couples" (EGE, 2004: 20). The 2004/23/EC Tissue and Cells Directive finally drew no distinction between commercial services and public banks and just requested the same standards for both. The decision and the precise manner in which to authorise or regulate private banks was, then, left to each member state - with the standards of the EU Directive taken as a minimum foundation. This could be considered an example of what Faulkner and his collaborators say about the European regulatory framework for biotechnology: European regulation focuses on quality and safety assurance and on the contribution of biotechnology to the economy while avoiding more thorny issues, such as ethics or questions of unproven clinical efficacy, which are left to the national jurisdiction of member states (Faulkner et al., 2008). 


\section{The National Transplant Organisation and the 'Spanish Model' of Organ Donation}

In order to understand the peculiar regulatory solution for UCB private banking in Spain, it is necessary to grasp certain aspects of the national context. This takes us to the field of transplantation and, more specifically, to the crucial institutional actor in the Spanish field, the National Transplant Organisation (ONT), and to what has been termed the 'Spanish Model' of organ donation (see, for example, Matesanz and DominguezGil, 2007). In the highly decentralised Spanish Healthcare System, where almost every responsibility related to health has been transferred to the regional governments, the field of organ, tissue and cell transplantation has kept a peculiarly centralised structure - though in a complex manner. The ONT is the national institution that is in charge of the coordination of organ procurement and transplant. It was created in 1989, after an alarming decline in the rates of kidney donation and an exponential growth of waiting lists during the second half of the 1980s (Miranda et al, 2001). Through its guidance, Spain has reached rates of 33-35 organ donors per million, the highest rate in the world. The ONT is the organisation in charge of the management of public UCB banking ${ }^{5}$ and it has played a crucial part in the regulation of private services, so it is important to understand its position, organisation and discourse.

The ONT belongs directly to the National Ministry of Health, which in theory means that it has no authority to intervene directly in the regional contexts. But there are two features that guarantee its central, and centralising, role in the field of transplantation. The first is its impressive rates of success, which provide it with an acknowledged legitimacy that is usually identified with the figure of its founder and current director, Rafael Matesanz. The second is its reticular structure, which somehow manages to overcome the regional fragmentation.

\section{Principles of the Spanish model of organ donor recruitment}

- Transplant coordination network, with three levels: national, regional and hospital

- Inter-regional council as organism of coordination and decision-making

- Central role of the hospital coordinator

- Continuous audit on brain deaths and outcome of donation at ICUs

- Central office as a support agency

- Great effort in training

- Hospital reimbursement

- Close attention to the media

- Unequivocal legislation (with clear definitions of brain death, of conditions of organ extraction, of absence of economic incentives...)

\section{Adapted from Quigley et al. (2008) and www.ont.es}

Table 1. The Spanish Model of organ donation. 
The ONT, in a sort of tentacular manner, is present in the regional healthcare political institutions - the regional coordinators of transplants belonging simultaneously to the regional health ministries and to the ONT - and in the hospitals - through the transplant coordinators present in virtually every ICU big enough. It thus manages to combine the efficiency of local organisations and the scope of large structures (Miranda et al., 2001).

Sometimes it has been argued that the reason for the success of the 'Spanish model' is found in a legislation that assumes presumed consent for cadaveric donations, but, as Quigley et al (2008) recognise, this cannot be the key factor in the high rates of donation, given that other EU countries with presumed consent, such as Greece and Bulgaria, are among the ones with lower donation rates. ${ }^{6}$ The success is instead explained by the organisational model of the ONT and by other features of the system, which are summarised in table 1.

The ONT assumes a triple function: a technical function of coordinating the activities of donation, extraction, preservation, distribution, exchange and transplantation of organs, tissues and cells in the whole of the Spanish Territory; an advisory function to state and regional authorities in everything related to transplants, including advice over norms and regulations; and an information and sensitizing function, aimed towards the general population. Given this combination of technical, political and social functions, which makes the ONT more than a purely technical body, the discourse and self-representation of the organisation are of a peculiar nature. In respect to promoting donation, the powerful rhetoric of organ scarcity (Scheper-Hughes, 2000) is always there but, being the world leader in donation rates, the ONT discourse is more complex than a simple call to unlimited donation. Both the altruism of the citizenship and the existing organisational disposition are hailed, but in the self-representation of the ONT, social values are portrayed as an effect of organisational success, and therefore, as an element that is somehow produced by the ONT and the whole public system. ${ }^{7}$ As one person of the ONT states talking about a supposed crisis of the model of altruistic donation in other countries:

... I do not think that there is a crisis in the model, what happens is that in other countries they have not managed to make it function properly. It is a crisis caused by an organisational problem. They have not had the organisational capacity to maintain or raise the rates of donation, and this produces in people the idea that the probabilities you have of receiving a transplant are but few, because there is a long waiting list, so you stop believing in the system. In Spain people believe in the system because they see that it is the country in which you have higher probabilities of being transplanted. And this is due to the solidarity of Spaniards, of course, but much more to the organisational system (ONT medical director, June 2008) ${ }^{8}$

So, portraying solidarity as an effect of the organisational aspects, an extremely strong identification is produced between the ONT as a public organisation, the discourse on altruism and the success in organ procurement. The ONT acts, then, as a guarantee, simultaneously, of a series of social values and of the public character of organ, tissue and cells transplantation. This is made evident in how the opening paragraph of the Spanish Tissue and 
Cells Act modifies the opening of the EUTCD. While the European directive states quality and safety as its main objective and reads: "The transplantation of human tissues and cells is a strongly expanding field of medicine offering great opportunities for the treatment of as yet incurable diseases. The quality and safety of these substances should be ensured, particularly in order to prevent the transmission of diseases" (2004/23/ EC, 1), the translation into the Spanish Act changes the order of preferences: "The transplantation of human tissues and cells is a strongly expanding field of medicine offering great therapeutic possibilities for many patients. Their increasing clinical use requires the implementation of a norm which partakes of the principles of voluntary character, anonymity between donor and host, altruism and solidarity that characterise the model of the Spanish National Healthcare System" (RD 1301/2006, Preface). In the Spanish version, quality and safety are a consequence of the adherence to the social values of altruism and solidarity, values that are guaranteed by the public management of the system and by the very existence of the ONT. Thus, the ONT can be judged as a perfect example of an institution of a Titmussian 'gift economy', with an added emphasis in the organisational form which, in a sense, ends by making equivalent the gift relationship (social altruism and solidarity) with the ONT and with the current (public) form of organisation.

The ONT is also a very active actor in the international field of transplantation, especially through the international promotion of the 'Spanish Model' and the participation in diverse forums on transplantation. The ONT is in charge of the Global Observatory on Donation and Transplantation, in collaboration with the WHO (World Health Organization), and takes part in a number of European and Latin-American projects on the promotion of public donation and improvement of transplantation practices (Matesanz et al., 2008). In these international activities, the ONT presents the adoption of the 'Spanish Model' as a key to improving rates of donation and also (specially in the EU) acts as a defender of public and altruistic systems of organ collection. Here it is possible to see (as the very idea of a 'Spanish' model shows) that a final characteristic of the position of the ONT is his symbolic attachment to the national territory: the model relies in its identification with the national territory, to the point in which circulation of tissues and organs beyond national boundaries is something that is, to a certain extent, invisible in the official discourse. It is true that the high rates of donation imply that there is usually no need to import organs, but the Spanish system exports high numbers of organs and tissues to other European countries, and UCB, in particular, is a tissue which Spain imports: $50 \%$ of the UCB transplanted in 2007 in Spain came from other countries, with a whole $30 \%$ imported from the USA (Haematopoietic Progenitors Report 2007, ONT).

\section{The debate over private cord blood banks}

It is in this context of strong organisational commitment to public systems of donation and to a national model where private UCB banks made their entrance. Since the beginning of collection in the mid-90s, the ONT was institutionally in charge of cord blood, since it was understood as a direct evolution of bone marrow transplantation. The first banks were started by regional authorities, and they are still under its direct responsibility, but the ONT watches over the whole 
system of public banks, guaranteeing and coordinating the collection, supply and distribution in all the Spanish territory.

It was not until several years later, around 2000, that the first requests of commercial firms to operate in national territory arrived, and around the same time, the ONT started also to receive queries from particulars over the possibility of banking privately the cord. What worried the ONT was how the introduction of money could "distort" the system:

We were really afraid at the beginning because the whole model is based in the fact of being free, and it works so well because it is based on that. One is never paid for donating, not a penny. In our country the model is based on altruism, solidarity... and a free transplantation. Not in every country is like that: in the United States, if you don't have money you don't get a transplant! But here... everything moves in the public arena, and at the very moment that you introduce an economic factor, everything starts to get distorted (ONT medical director, June 2008)

For a time, requests for licences were automatically rejected, under an interpretation of the 1999 Transplantation Act (even though nothing in that legal text mentioned cord blood banks). The founder of Vidacord, a private UCB bank, refers repeated attempts to be licensed in different regions and how each time, through the regional transplantation coordinator of the ONT, the licence was denied (Private bank, June 2008). But even though these requests were invariably rejected, in fact several foreign companies had started to operate in Spain through the Internet: offering their services on-line and advertising their services in magazines for parents, these companies sent the collected samples to banks situated in other European countries - mainly Portugal, the UK and Belgium. But the visibility to the wider public of UCB private banks would come through an unexpected controversy.

In February 2006, news appeared in the Spanish press that the umbilical cord of the Princes' first child had been sent to a North-American private tissue bank for its processing and storage. Like "hundreds of other Spanish couples", reported El País, the newspaper that broke the news, the Princes had decided to collect the blood from the umbilical cord of their daughter during labour and to send it abroad for cryopreservation. In the midst of a controversy caused by the Royal Family using a service that was still unregulated - it was even illegal, some commentators suggested - and that was opposed to the spirit, if not the letter, of Spanish Law, a spokesperson from the Royal Household promptly stated to the press that it was the medical team who proposed to the Princes the possibility of collecting and storing the umbilical cord, being a standard procedure in the (private) clinic where the Princess gave birth.

The decision of the Princes unleashed a public debate in the Spanish press, in which several social actors took sides. Most medical societies and progressive newspapers supported the views of Rafael Matesanz, the director of ONT, who declared that "there is no scientific background for private banks", implicitly criticising the decision of the Royal Family, and that private banks were "a wasp in the system". ${ }^{9}$ On the contrary, César Nombela, former president of the Spanish National Research Council (CSIC) and president of the Advisory 
Group on Ethics of Research, declared that the Princes had acted "very reasonably", not only because "the therapeutic potential of UCB is increasingly evident", but because "its preservation does not present any ethical objection." ${ }^{10}$ Several other actors, from the conservative Popular Party (PP) to the Church, shared the views of the latter and his support of private banks, on two different grounds: the defence of the market and of the freedom of choice for parents, and the ethical "unquestionability" of UCB stem cells compared to human embryonic stem cells. This public debate, which was a regular presence in the press during several months, would inform the future regulation of UCB private banks.

Two more events happened around the date in which the new Tissue and Cells Act was passed, November 2006. The first one made manifest the political confrontation of the two main parties with respect to this subject: the Regional Government of Madrid, in the hands of the PP, passed a regulation authorising, without almost any restriction, the activities of private banks. The regional authorities were immediately taken to court by the Socialist central government, as the national act was about to be promulgated, and the fight on tribunals went on until 2008, when the Constitutional Court finally decreed the superior character of the (much more restrictive) governmental act. A second event also happened in Madrid: it was revealed in the press that two public hospitals in the region had disposed of 140 umbilical cords that had been donated to the public system. In this case, what was put into circulation and debate through the media was how the character of waste of the cords is being modified. As Waldby and Mitchell explain, the discourse of a transformation "from garbage to gold", from a waste product to a valuable and promissory source of stem cells, is crucial in the contemporary debates around UCB (Waldby and Mitchell, 2006: 114-117)

The whole debate in Spain revolved around two questions. The first one concerned the scientific background of private banks: is there any real evidence for the private conservation of the cord? A war on numbers on the likelihood of using a privately-banked sample was carried out between supporters and opponents of private banks. What was being debated here was, in part, a temporal question, an opposition between present applications and future possibilities - between a regime of truth and a regime of hope (Martin et al., 2008). But the scientific debate quickly gave way to a different area of discourse, and the debate was then posed on sociopolitical grounds, opposing the discourse on altruism and solidarity championed by the ONT and the public authorities to the liberal discourse on individual choice and freedom of the market that was used by those who supported private banks. It is in these political terms in which the regulation of commercial services was finally posed.

\section{The 2006 Tissue and Cells Act and its consequences}

Unlike the European directive, the $\mathrm{RD}$ 2006/1301 or Spanish Tissue and Cells Act deals specifically with private cord blood banks, or more specifically, with tissue banks for autologous applications. They are mentioned already in the preface to the Act, to question at the same time the existence of any scientific evidence to support them and their desirability in the European space: "There is no current scientific base for the preservation of cells or tissues for a possible autologous application, nor do European institutions 
support this practice". The ONT first thought of recommending to public authorities a complete prohibition of the activities of private banks, but "it is a solution... that doesn't leave options, that is too strict; it would be criminalizing it" (ONT medical director, June 2008). This precaution towards excessively strict measures would later condition also the enforcement of the regulation, as we will see below. ${ }^{11}$

The solution finally adopted legalised private banks, but only under very strict conditions. First of all, and being the gist of the approach adopted here, the Act states that any sample deposited in a private bank will be available to the public system for allogeneic use, and that it could be requested if any other patient needs it. In the view of private banks, this disposition is effectively challenging the private ownership of the samples and has been thoroughly criticised. Second, the Act obliges all tissue banks to be "nonprofit" in order to get a licence, so the altruistic and free character of donation and transplantation is preserved. Finally, it is necessary to have a formal and signed agreement between the cord blood bank, be it private or public, and the hospital or clinic where the tissue is collected. Apart from that, other parts of the Act also address, directly or indirectly, private banks. There is an explicit prohibition of "misleading advertising", defined as any "advertising that induces misunderstanding about the real utility of obtaining, processing and preserving cells and tissues for possible autologous use, according to the available knowledge and experiences". Finally, the Act puts severe limitations on the exportation of tissues and cells, something that should have affected the hitherto usual practice of hiring the services of foreign banks and sending the cord abroad.
This regulation is unprecedented, as no other country has tried a solution like this. If there are other "hybrid" forms of UCB banking (such as Virgin Health Bank, a dual private-public British bank where the cord is divided in two units, one donated to the public system and the other kept for potential private use), a legal obligation to provide privately stored samples to the public system cannot be found anywhere else. According to the ONT, Italy - a country in which private banks are currently unlawful - is thinking of adopting the same approach. So it is illuminating to analyse what have been so far the consequences of this regulation.

To begin with, the application of the Act has hindered the development of a national private sector in cord blood banking in Spain. So far, only one commercial bank, Vidacord S.L., has been licensed and is fully carrying out operations in the Spanish territory. But the point lies in that this company has been the only one to carry out the full process, ${ }^{12}$ because the rest of services that were operating in Spain before the passing of the Act have continued offering their services through the Internet and storing the samples abroad, directly ignoring the new rules. The director of Vidacord considers that, economically, the bank has been "a total ruin" (due to the investment made in having a laboratory to fulfil the complex standards that the Act requires), while the un-licensed services that are operating from abroad are, instead, a profitable business (Private bank director, June 2008). So it can be argued that the Act has not prevented the operation of foreign companies, even producing, to a certain extent, the conditions for an unregulated market In fact, through agreements with health insurance companies, private hospitals and even medical bodies, like the Society 
of Gynaecologists, the presence of private banks has greatly increased in the last 3 years. ${ }^{13}$

A second consequence is that the vast majority of the cord blood banked privately in Spain is being sent abroad, to banks in Belgium, Poland, Portugal or the UK. In the case of Vidacord, which keeps samples in Spain but also offers to its clients the possibility of sending the cord to Poland, the proportion of cords staying in the Spanish territory is less that 1 in 10. Most parents choose to send the cord abroad to avoid the remote, but real, possibility of the public system requesting it (Private bank director, June 2008). This means that the restrictions concerning exportation are not being applied, partly because of the caution towards excessive measures commented above and partly because there is no real numerical competition between the private and the public sector. In the following extract, one regional transplantation manager explains how the conflict between the public and private sectors is symbolic and political, but not quantitative:

The public system has relatively limited needs [...] What is sensible is conducting ourselves around quantities of $50,000,60,000$, units, ${ }^{14}$ something that can be achieved in a limited amount of time, and then an annual replacement, a few thousands, would do... But there are 400,000 annual births in Spain, so there would be space for the private sector... It would be problematic because of what it implies, but then that's already a different question... It is a question of its impact on solidarity, et cetera, but not of numbers. (Regional coordinator, June 2008)

Perhaps the most paradoxical consequence of the regulation is that its application is reflecting and, to some extent, deepening, an opposition in Spain between private and public healthcare. Given that the public system does not aspire to collect every cord, donating the cord to a public bank is not an option available in every hospital - and is particularly absent in private clinics, which have very rarely signed an official agreement with a public bank. The ONT medical director talks of "two completely different models", where "people giving birth in public maternities donate to the public system and people giving birth in private clinics keep the cord to themselves" (ONT medical director, June 2008). But the corollary is that some people, ascribing high symbolic and material value to the stem cells in the cord and finding it difficult to preserve it when attending public hospitals, are directed towards private healthcare. One of my interviewees, a young first time mother, resolved her indecision at giving birth on a public or a private clinic when learning that it would be impossible to bank the cord privately in a public hospital (Mother, June 2008).

In a somewhat material turn, it can even be argued that we find in the public and private sector two different objects: since the cords preserved by private companies and sent abroad do not pass the quality controls and transformation procedures that the ones preserved in the public system are subjected to, a sample privately banked and one in a public bank are different things. The public system throws away more than 3 out of 4 donated cords, selecting only the ones with a sufficiently high cellularity, while in the commercial services very few samples are rejected (Regional coordinator, June 2008; Private bank medical director, October 2008). Furthermore, procedures for collecting and processing are different in the two sectors, with some private 
companies even dividing the units to facilitate sending and storage - a division that, it is normally to accepted, makes the sample useless for current therapies. The fact that, through exportation, commercial services are avoiding the application of regulatory controls means that the desired standardisation of practices and materials is not happening. Differing practices and/or absence of standards, in a field still as unstable as stem cell science, entail onto-technical consequences (Eriksson and Webster, 2008).

As a result of all this, public and private cord blood banking sectors appear to be forming around them different sociotechnical networks, or better, different "biosocialities" (Rabinow, 1996). This goes as far, I would argue, as to be managing different bio-objects. While regulation was designed to prevent the introduction of the private sector - associated, in the discourse of the ONT, with a "perversion" of the values attached to the public system - some of its (unintended) effects seem to be the deepening of the fragmentation between private and public healthcare systems and the facilitation of what a newspaper termed a "flight of the cords" to other countries. ${ }^{15}$ But the debate has not been settled still. Companies continue demanding a relaxation of the legal framework and it is still to be seen how regulation could change or evolve in the near future, as well as how public attitudes and the strategies of private banks and public actors will modify.

\section{Conclusion}

I have presented in this paper a process of regulation of a peculiar "human boundary object", umbilical cord blood, focusing particularly on the political side of the process. A debate over the effect of UCB private banking on the existing political economy of transplantation, based on altruistic donation and national solidarity, has guided in Spain the enactment of a regulatory framework which puts severe limitations on commercial services. This has prevented the development of a commercial sector in national territory. However, one of the consequences of this regulation has been the generation of a circuit of exportation of privately-banked units to other countries, something which not only extracts these samples from public quality and safety controls, but also reinforces, to some extent, the detachment of some users from the public system and its solidaristic ideology.

The Spanish case has been taken here as an example of some of the problems currently faced by national regulations and by public systems of transplantation, and of the unintended consequences that certain national regulatory processes can originate. An issue that appears quite clearly in the hitherto resolution of the Spanish case, particularly in the circulation of cords beyond the national boundaries, is that it is increasingly difficult to contain biomedical objects inside a closed regulatory framework. Several features of the private cord blood sector - beginning with its webbased character, something that has also been identified as a challenge for the governance of technology in fields such as direct-to-consumer pharmaceutical advertising (Fox et al., 2006) - authorise us to understand it as a peculiar technological zone, in Barry's sense, one which poses a spatial challenge to the sovereignty of national authorities. A link could be established with the problem of stem cell tourism, that is, the growing phenomenon of patients travelling to other countries to receive unproven and unregulated stem cell therapies, against 
which the International Society for Stem Cell Research has recently warned (Baker, 2008). But even though these trends are evidently problematic, they also have to be acknowledged as part of a wider phenomenon of increasing worldwide circulation of organs, cells and tissues in contemporary tissue economies. Martin et al. point out how the US National Cord Blood Program, the biggest public bank in the world, had by 2006 delivered units to 199 centres in 30 countries, also noting the striking feature of "American blood" being distributed internationally, instead of staying inside the national boundaries of a recognizable imagined community (Martin et al., 2008: 136137). The increasing mobility of human boundary objects through what Nikolas Rose terms circuits of vitality (Rose, 2007: 38 ), challenges the former biopolitical identification between the supply of blood, organs and other bodily fragments and the body politic as contained within the limits of the nation-state, an identification that has been in the base not only of blood and organ donation for transplants, but also of other kinds of "altruistic" practices for the benefit of the national "imagined community", such as the procurement of tissues and personal health data to national genetic databases (Busby and Martin, 2006).

In a similar sense, it seems to me that the conflict between the ONT and private banks can be understood as the opposition of two forms of biopolitics, two dispositions of biopower (Foucault, 1998; Rose and Rabinow, 2006). It can be argued that the Titmussian "gift relationship", basis of the public transplantation systems, was a rationale embedded in the bio-politics of the population pictured by Foucault: state-led through regulatory controls, here we find a relationship between the anonymous solidarity that links donor and recipient and the constitution of a subjecthood that is, simultaneously, biological and national (Foucault, 1998: 135-159). By contrast, the private UCB bank echoes recent mutations in biopolitics, as described by some scholars. For example, the shift that Herbert Gottweis detects in the governance of genomics from countable risk to uncountable uncertainty, a shift that implies a parallel change from calculable prevention to uncertain precaution (Gottweis, 2005), or the transition, thoroughly detailed by Nikolas Rose, from the exercise of a "pastoral power" by the State to the precautionary action of the "somatic individual" (Rose, 2001, 2007). The tension between two biopolitical logics is therapeuticallyvisible in the opposition between autologous and allogeneic. If public systems work with reference to an allogeneic rationale which, in its socio-political translation, implies a redistributive tissue economy, private banks, on the contrary, have as their cognitive frame the promise of regenerative medicine, that is, the idea of self-repair of an isolated body, a body secluded from the solidaristic networks of tissue exchange. ${ }^{16}$ Of course, the logical division between the two sectors is not so neat in real life - where we find hybrid banks, or where, as stated above, the transnational circulation of tissues is also part of the public system - but what is important here is understanding that private banking is more than a temporary or conjunctural phenomenon; it is part of wider mutations in the deployment of biopolitics.

In fact, a plethora of new commercial services related to stem cells - mainly in the US market - is being currently modelled in the image of the private UCB bank. Among them we can list not only private storing of leftover embryos 
for couples who have undergone IVF (a supply which, as it is well known, has been until today the major source of embryos for research), but also companies that offer process and storage of diverse waste bodily tissues said to be sources of stem cells, from fat removed by liposuction to children's baby teeth (Nelson, 2008). The last addition to this scene is C'elle, a new service launched by Cryo-Cell International (one of the first UCB private banks), which offers the opportunity to women to store "potentially life-saving stem cells found naturally in menstrual blood" (http://www.celle.com/). It is likely that social and regulatory challenges will continue to emerge from these private transformations of human boundary objects, and that further reflection about the difficulties and consequences of their governance will be needed.

\section{Acknowledgements}

This article is based on fieldwork and data from a research project involving literature review, analysis of media coverage and interviews $(\mathrm{n}=14)$ with key stakeholders in the Spanish public and private cord blood banking sectors, funded by a postdoctoral grant from the Spanish Ministry of Education ("Expectativas y Modos de Regulación de los Bancos de Cordón Umbilical: una comparación entre el Reino Unido y España", MEC/FECYT Contrato PostDoctoral 2007-0386). The author would like to express his gratitude to Nik Brown, Helen Busby, Klaus Hoeyer, Darren Reed and two anonymous reviewers for their useful comments and suggestions, as well as to the participants in the panel "Governing Multiple Tissue Economies? Exploring the Practices and Policies Shaping the Uses of Human Tissues and Cells in the European Union", 4S/EASST
Joint Conference, Rotterdam 20-23 August 2008, where a preliminary version of this paper was first presented.

\section{Notes}

1 Some critics of Titmuss (e.g. Arrow, 1972) have argued that, when addressing the question of altruism in blood donation, Titmuss confused two different levels of analysis, the individual (the psychological factors influencing the decision whether to donate or not) and the collective (the political properties of national solidarity and social cohesion), levels that should be considered separately. Reading Titmuss's argument in the light of Foucauldian biopolitics, as I do here, is a way of overcoming that (theoretically unjustified) separation between levels: the subjective and the political are here understood as part of the same regime of discourse and constituted by the same technologies of government.

2 For instance, determining if the cord is biologically foetal or maternal tissue is important in determining who is legally the owner of the blood and how informed consent for purposes of donation or banking has to be regulated (Annas, 1999).

3 Some commentators, nonetheless, claim that the collection of the cord might interfere, in one way or another, with the performance of the medical team and the British Royal College of Gynaecologists and Obstetrics warns explicitly against this (RCOG, 2006). Some of the criticisms of Dickenson (2007), from a feminist point of view, rely on the inattention to the necessities of the mother during cord blood collection 
and on the "potential unknown damages" in the long-term for the child.

4 There are certain disadvantages, too, in the use of UCB: particularly, that the cellularity, or amount of stem cells, in a UCB sample is very low, so most of the transplants have been carried on so far in children. Several avenues are currently being followed to develop a procedure for adult transplantation, including a double graft and the expansion of cells in culture.

5 The positioning of cord blood along organs and tissues, and not along blood, has here important effects for its regulation. Contrary to organs, blood collection and donation is in Spain a fully decentralised field, in charge of hospitals, regional authorities and the Red Cross. There is no central blood service.

6 And also, in the Spanish case, because the next of kin has legally an effective veto and, in practice, "families are always approached as a way of understanding the wishes of the deceased about donation, or as a way of getting permission to proceed with donation if the wishes of the deceased are unknown. Organs are not taken in Spain against the wishes of bereaved relatives. Therefore, from a practical point of view, an explicit or opting-in model continues to be applied" (Quigley et al., 2008: 223).

7 The American sociologist Kieran Healy adopts a similar stance when taking an organisational approach to explaining variation in rates of organ donation throughout the US. For Healy, altruistic donation should be understood as a variable dependent on several logistical features of the organ procurement organisations, so ultimately "the production of altruistic action can be thought of as a resource extraction problem for organisations" (Healy, 2004: 400).

8 All following references to interviews come from the transcriptions of recordings and have been translated by the author. The interviews were conducted in June, October and November 2008 in Madrid and Barcelona.

9 Interview with Rafael Matesanz, El País, 27/01/2006.

10 "La congelación del cordón umbilical de la hija de los Príncipes de Asturias desata un intenso debate" [The freezing of the Princes' daughter cord unleashes an intense debate], El Mundo 27/02/2006.

11 Barry also notes this caution of liberal forms of government (particularly evident in the governance of the economic field) towards excessive intervention, something that directly influences the constitution of de-centralised technological zones: "Such an economy is, it is argued, necessarily too complex, and too dynamic, to be controlled from the centre and any attempt to direct it on the basis of one partial perspective would, in the end, be counter-productive. Centralised control should not necessarily be avoided, but it should be exercised with caution" (Barry, 2001: 12).

12 Another private company, CrioCord, has been licensed but it is not preserving samples in Spain. It does not even possess a bank in national territory: "What for?", declares the director of the company, "Parents do not want to leave the cord here, they'd rather send it abroad and be 
assured that they are the only ones who could use it in the future", $E l$ País, 11/01/2009

13 According to a recent press article, the number of units in private foreign banks (circa 30.000) equals that of the public system, El Pais, $11 / 01 / 2009$.

14 Currently there are around 28,000 units stored in Spain in 6 public banks (Haematopoietic Progenitors Report 2007, ONT, report available at:

(http://www.ont.es/estadisticas/ ficherosZip/mem2007.zip)

15 "Cordones Umbilicales a la Fuga" [Umbilical cords fleeing], El País, 26/10/2007.

16 In the discourse of private banks, autologous therapies are the promise, but nonetheless, there is also increasingly a com-promise in the marketing of commercial services, the idea of "intrafamilial allogeneic", a kind of autologous rationale extended to the whole family unit and that, in the last four or five years, has turned into the prevailing theme in the advertising of commercial services. Following this discursive shift - which is also a strategic one, for, as the director of Vidacord told me, "banks that are in the autologous rationale are the ones really pursued by the ONT. Where is it more difficult to be criticised? It's in the idea of allogeneic transplants from a related donor" (Private bank director, June 2008) - would take us to the contemporary redefinitions of kinship and family in the context of the new biotechnologies, something noted by Brown and Kraft (2006).

\section{References}

Annas, J. (1999) 'Waste and Longing. The legal status of placental-blood banking, New England Journal of Medicine 340 (19): 1521-1524.

Arrow, K. (1972) 'Gifts and Exchanges', Philosophy and Public Affairs 1(4): 343-362.

Baker, M. (2008) 'Stem cell society condemns unproven treatments', Nature Reports Stem Cells, 26 June 2008.

Barry, A. (2001) Political Machines. Governing a Technological Society (London and New York: The Athlone Press).

Brown, N. \& A. Kraft (2006) 'Blood Ties: Banking the Stem Cell Promise', Technology Analysis \& Strategic Management 18 (3/4): 313-327.

Brown, N., A. Faulkner, J. Kent \& M. Michael (2006) 'Regulating Hybrids: "Making a Mess" and "Cleaning up" in Tissue Engineering and Transpecies Transplantation', Social Theory \& Health 4(1): 1-24.

Busby, H. \& P. Martin (2006) 'Biobanks, national identity and imagined communities: The case of UK Biobank', Science as Culture 15 (3), 237-251.

Cooper, M. (2004) 'Rediscovering the Immortal Hydra: Stem Cells and the Question of Epigenesis', Configurations 11(1) 1-26.

Dickenson, D. (2007) Property in the Body: Feminist Perspectives (Cambridge: Cambridge University Press).

Edozien, L. (2006) 'NHS maternity units should not encourage commercial banking of umbilical cord blood, British Medical Journal 333: 801-804.

EGE (European Group on Ethics in Science and New Technologies) (2004) Ethical Aspects of Umbilical Cord Blood Banking. Opinion no. 19 to the European Commission, 16 March 2004. 
Eriksson, L. \& A. Webster (2008) 'Standardising the Unknown: practical pluripotency as doable futures', Science as Culture 17(1): 57-69.

Faulkner, A., I. Geesink, J. Kent \& D. Fitzpatrick (2008) 'Tissue-Engineered Technologies: Scientific Biomedicine, Frames of Risk and Regulatory RegimeBuilding in Europe', Science as Culture 17(2): 195-222.

Fisk, N., I. Roberts, R. Markwald \& V. Mironov (2005) 'Can routine commercial cord blood banking be scientifically and ethically justified?', PLoS Med 2 (2), e44: 87-90.

Foucault, M. (1998) The Will to Knowledge. The History of Sexuality, Volume 1 (London: Penguin).

Foucault, M. (2004) Society Must Be Defended. Lectures at the Collège de France 1975-1976 (London: Penguin)

Fox, N., K. Ward \& A. O’Rourke (2006) 'A Sociology of Technology Governance for the Information Age: The Case of Pharmaceuticals, Consumer Advertising and the Internet', Sociology 40(2): 315-334.

Gluckman, E., H.E. Broxmeyer \& A.D. Auerbach (1989) 'Hematopoietic reconstitution in a patient with Fanconi anemia by means of umbilical cord blood from HLA identical sibling', New England Journal of Medicine 321: 1174-1178.

Gottweis, H. (2005) 'Governing genomics in the 21st century: between risk and uncertainty', New Genetics and Society 24(2): 175-194.

Gunning, J. (2004) 'A worldwide study of umbilical cord cell banking', study accompanying EGE Opinion No 19 on Ethical aspects of umbilical cord blood banking.

Healy, K. (2004) 'Altruism as Organizational Problem. The Case of Organ Procurement', American Sociological Review 69: 387-404.
Hoeyer, K. (2007) 'Person, Patent and Property: A Critique of the Commodification Hypothesis', BioSocieties 2(3): 327-348.

Jasanoff, S. (2005a) Designs on Nature: Science and Democracy in Europe and the United States (Princeton: Princeton University Press).

Jasanoff, S. (2005b) 'In the democracies of DNA: ontological uncertainty and political order in three states', New Genetics and Society 24(2): 139 -156.

Kent, J., A. Faulkner, I., Geesink \& D. Fitzpatrick (2006) 'Culturing Cells, Reproducing and Regulating the Self', Body and Society 12(2): 1-23.

Lock, M. (2001) Twice Dead: Organ Transplants and the Reinvention of Death (Berkeley: University of California Press).

Martin, P., N. Brown \& A. Turner (2008) 'Capitalizing Hope: the commercial development of umbilical cord blood stem cell banking', New Genetics and Society 27(2): 127-143.

Matesanz, R. \& B. Dominguez-Gil (2007) 'Strategies to optimize deceased organ donation', Transplantation Reviews 21: 177-188.

Matesanz, R., B. Dominguez-Gil, E. Martín Escobar, B. Mahillo, M., Carmona, A., Luengo \& M. Álvarez (2008) 'La traslación del modelo español a otros países. Cooperación Internacional' [The translation of the Spanish model to other countries. International cooperation], in R. Matesanz, R. (ed), El Modelo Español de Coordinación y Trasplantes (Madrid: Aula Médica).

Miranda, B., J. Cañón, N. y Cuende (2001) 'The Spanish Organizational Structure for Organ Donation: Update', Transplantation Reviews 15(1): 33-45.

Nelson, B. (2008) 'Stem Cell Banking: Lifeline or subprime?', Nature Report Stem Cells http://www.nature.com/ stemcells/2008/0803/080313/full/ 
stemcells.2008.48.html. Published online: 13 march 2008.

Nowotny, H., P Scott \& M. Gibbons (2001) Re-Thinking Science: Knowledge and the Public in an Age of Uncertainty (Cambridge, Polity Press).

Quigley, M., M. Brazier, R. Chadwick, M. Navarro \& D. Paredes (2008) 'The organs crisis and the Spanish model: theoretical vs. pragmatic considerations', Journal of Medical Ethics 34: 223-224.

Rabinow, P. (1996) 'Artificiality and Enlightenment: From Sociobiology to Biosociality', in P. Rabinow, Essays on theAnthropology of Reason (Princeton, NJ: Princeton University Press).

Rose, N. (2001)'The Politics of Life Itself', Theory, Culture and Society 18(6): 1-30. Rose, N. (2006) The Politics of Life Itself. Biomedicine, Power and Subjectivity in the Twenty-First Century (Princeton University Press).

Rose, N. \& P. Rabinow (2006) 'Biopower Today', Biosocieties 1(2): 195-217.

RCOG (Royal College of Obstetricians and Gynaecologists) (2006) Umbilical Cord Blood Banking, Scientific Advisory Committee Opinion Paper 2, available in: http://www.rcog.org.uk/resources/
Public/pdf/umbilical_cord_blood banking sac2a.pdf (last accessed: 25 September 2008)

Scheper-Hughes, N. (2000) 'The Global Traffic in Human Organs' (2000), Current Anthropology 41 (2): 191-224.

Steinbrook, R. (2004) 'The cord-bloodbanks controversies', New England Journal of Medicine, 351(22): 22552257.

Titmuss, R. (1997) [1970] The Gift Relationship: From Human Blood to Social Policy (London: LSE Books).

Waldby, C. (2006) 'Umbilical Cord Blood: From Social Gift to Venture Capital', Biosocieties 1(1): 55-70.

Waldby, C. \& R. Mitchell (2006) Tissue Economies. Blood, Organs and Cell Lines in Late Capitalism (Durham and London: Duke University Press).

Webster, A. (2008) 'Prospective regulation in a globalised world: the view from social science', Working Paper (York: Centre for Prospective Regulation).

Pablo Santoro

Science and Technology Studies Unit (SATSU) Department of Sociology University of York, United Kingdom ps548@york.ac.uk 